\title{
Effect of Blended NPS Fertilizer and Varieties on Seed Quality, of Bread Wheat (Triticum aestivum L.) Haramaya, Eastern Ethiopia
}

\author{
Mr. Demisew Amare(Msc) ${ }^{1^{*}}$ \\ 1 Collage of Agriculture and Natural resources, Bonga University P.O. Box 334, Bonga, Ethiopia \\ 2 Collages of Agriculture and Environmental Sciences, Haramaya University, P.O. Box 138 Dire Dawa, Ethiopia \\ Dr. Wassu Mohammed $(\mathrm{PhD})^{2}$, \\ Collages of Agriculture and Environmental Sciences, Haramaya University, P.O. Box 138 Dire Dawa, Ethiopia \\ Mr. Amare Kebede (Asst. Prof.) ${ }^{2}$ \\ Collages of Agriculture and Environmental Sciences, Haramaya University, P.O. Box 138 Dire Dawa, Ethiopia
}

\begin{abstract}
There is no information on the role of blended NPS fertilizer required to produce quality seeds of wheat in Ethiopia. Thus, this study was conducted to assess the status of how the quality of wheat seeds had been affected by NPS fertilizer. The laboratory experiment conducted during 2018 in completely randomized design (CRD) with four replications and the seeds of the three varieties evaluated/tested after harvesting of three bread wheat varieties planted in the field which is fertilized with eight blended fertilizer rates $(0,25,50,75,100,125,150$, and $175 \mathrm{~kg}$, $\mathrm{ha}^{-1}$ NPS fertilizer during 2017 cropping season. The seed quality test after harvest indicated that all seed quality parameters significantly influenced by separate effect of variety and the application of blended NPS fertilizer except moisture content of seeds not significantly influenced by the two factors and dead seeds not significantly influenced by varieties. The two factors interacted to influence only a thousand seeds weight and dead seeds. The result showed that highest value of the germination percentage $(95.17 \%)$, dry weight $(25 \mathrm{mg})$ and vigour index two (23.82) were recorded from the plot received $150 \mathrm{~kg} \mathrm{ha}^{-1} 1 \mathrm{t}$. Similarly highest mean value of the speed of the germination (30.41) and vigour index one (19.35) was recorded on the $175 \mathrm{~kg} \mathrm{NPS} \mathrm{ha}^{-1}$ fertilizers. In the case of the thousand seed weight significantly the highest (48.95 g) and the lowest (39.13) mean was recorded on the interaction effect of the Kakaba interact with $175 \mathrm{Kg}$ NPS fertilizer and Qulqulu interact with control treatments consecutively. Furthermore, the results of the experiment showed that significantly the highest mean value of the germination percentage (93.44\%), seedling shoot length $(9.48 \mathrm{~cm})$ seedling dry weight $(23.98 \mathrm{mg}$ and seed vigour index one (19.31) recorded on the Qululu and Shorima varieties respectively. The results indicate wheat crop seed quality attributes will be increased /affected due to the synergic effect of NPS fertilizer rate and genotype. Therefore, it can be concluded that the using of $150 / 175 \mathrm{~kg} \mathrm{NPS} \mathrm{ha}^{-1}$ and the growing of Qulqulu variety could be a better choice to obtain desired seed quality.
\end{abstract}

DOI: $10.7176 / \mathrm{JNSR} / 10-7-02$

Publication date: April $30^{\text {th }} 2020$

\section{Introduction}

Wheat is an important cereal crop in Ethiopia, which is cultivated in a wide range of altitudes (Hailu, 1991) and it is one of the most staple food crops cultivated in Ethiopia. Wheat is used in different forms such as bread, porridge, soup and roasted grain, and the straw of wheat is used for animal feed, thatching roofs and bed decking (Amare et al., 2015). Total wheat production in Ethiopia during 2016 Meher season was 4.2 million metric tons, which is accounting for 15.81 percent of the total grain production in the country (CSA, 2016). It ranks fourth after tef (Eragrostis tef), maize (Zea mays) and sorghum (Sorghum bicolor) in area coverage and of fourth in total production (CSA, 2016).

The national average yield for wheat is 2.5 tons $\mathrm{ha}^{-1}$ which is lower than the world average yield (3.19 tons $\mathrm{ha}^{-1}$ ) (FAOSTAT, 2013). The low yield per hectare attributed to many factors, such as unavailability of quality seed of improved varieties and use of poor quality of farmer-saved seeds and poor crop nutrition (Alemayehu, 2015). The poor quality seed results in poor germination and poor crop stands at the farm and become a significant factor affecting wheat productivity (Bewley and Black, 1994). A superior quality seed not only increases productivity per unit area, but it also helps to produce uniform crops without any admixtures, and important for obtaining high prices on the market (Nguyen 2001).

The seed production requires good agronomic management of the crop that differs from grain production, though the production of seed and grain in wheat follows similar operations (van Gastel et al., 2004). The application of fertilizer is among the agronomic management of wheat seed production, in which the types and amounts need to be determined for each area of production based on soil type, $\mathrm{pH}$ of the soil, organic matter 
content and many other factors (Brady and Weil, 2002

According to Ministry of Agriculture (2009), the national recommendation of Urea and DAP (Di-ammonium Phosphate) were $100 \mathrm{~kg} \mathrm{ha}^{-1}$, that farmers in most parts of Ethiopia are using for bread wheat grain production without considering the differences of soil types and fertility status. But this fertilizer only contains $\mathrm{N}$ and $\mathrm{P}$ fertilize which is not sufficient for, quality seed production. To solve this problem Ministry of Agriculture of Ethiopia has been recently introduced a new compound fertilizer (NPS) containing nitrogen, phosphorus and sulfur with the ratio of $19 \% \mathrm{~N}, 38 \% \mathrm{P} 2 \mathrm{O} 5$ and $7 \% \mathrm{~S}$ as the main source of phosphorous (MoANR, 2013). However, adequate information on NPS fertilizer and varieties effect on seed quality of Wheat and the resulting losses of seed qualities is not well studied. Therefore, the present study was conducted to assess the status of how the quality of wheat seeds had been affected by NPS fertilizer.

\section{Materials and methods}

The laboratory experiment was conducted in Seed Science and Technology laboratory of Haramaya University, in 2018. A one kg seed of the three wheat varieties ( Shorima,Kakaba and Qulqulu) taken after threshing which was harvested during 2017 cropping season. These bread wheat varieties were planted/ fertilized with eight blended fertilizer rate $\left(0,25,50,75,100,125,150\right.$ and $175 \mathrm{~kg} \mathrm{ha}^{-1}$ and examined for seed quality difference at Haramaya University Seed Science and Technology Laboratory in 2018. The 400 seeds were randomly taken from each variety for seed quality analysis. The test was conducted in completely randomized design (CRD) with four replications, consisting 100 seeds for each replication, where appropriate seeds were surface-sterilized in $10 \%$ solution of commercial sodium hypochlorite $(\mathrm{NaOCl})$ laundry bleach for five minutes, rinsed several times with sterile distilled water, placed on sterile paper towels to dry before quality examination procedures. The germination was tasted on filter paper. The germination test was carried out at room temperature $\left(20^{0} \mathrm{c}\right)$, daylight and optimal moisture level for eight days. The germination of seeds in each Petri dish was observed and every day and the number of germinated seeds were counted as per International Seed Testing Rules (ISTA, 2014).

\subsection{Data collected from a laboratory experiment}

Moisture content (percentage): five gram of seeds from each variety and each treatment combination in each replication was taken from the sample seeds, grinded, weighted poured into a small container and covered with aluminium foil for pre-dry measurement. Samples were dried under a low constant temperature oven method. At the end of two hours, containers were placed in desiccators for 30 minutes. After cooling, the container weighed with its cover and contents, and the moisture content of seeds was determined by the following formula (ISTA, 2014).

\section{The moisture content of a seed $(\%)=\frac{\mathrm{M} 2-\mathrm{M} 3}{\mathrm{M} 2-\mathrm{M} 1} \times 100$}

Where; M1 is the weight of the container; M2 is the weight of the container and the weight of the seed and M3 is the weight of the seed and the container after oven drying.

Thousand seeds weight (g): randomly taken 1000 seeds of each variety and each treatment combination in each replication were weighted, adjusted to $12.5 \%$ moisture content and registered.

Germination test: was done for all seed samples obtained from the store as initial seed samples of the three varieties and different treatment combinations from a field experiment. Two hundred (400) seeds of the pure seed components were divided into four replicates of 100seeds each, which was sown top of the paper in Petri dishes. On the final day of the standard germination test, germinated seedlings were evaluated into normal seedlings, abnormal seedlings, and dead seeds to determine the percentage of each category of seedlings

\section{Number of normal seedlings} Total number of seeds sown $\times 100$

Germination percentage $(\%)=$

The speed of germination: The same procedures were used with that of germination percentage, but the only difference was the numbers of normal germinated seeds were recorded daily until further germination stops. The speed of germination was calculated by adding the ratio of daily counts of normal seedlings divided by the number of day's germination.

Speed of germination $=\frac{\mathrm{N} 1}{\mathrm{C} 1}+\frac{\mathrm{N}_{2}}{\mathrm{C}_{2}}+\ldots+\frac{\mathrm{NF}}{\mathrm{CF}}$

Where: $\mathrm{N} 1=$ number of normal seedlings at first count, $\mathrm{N} 2=$ number of normal seedlings at the second count, $\mathrm{NF}=$ number of normal seedlings at final count, $\mathrm{C} 1=$ days to the first count, $\mathrm{C} 2=$ days to the second count and $\mathrm{CF}=$ days to the final count.

Seedling shoots and root length $(\mathbf{c m})$ : The seedlings shoot length and root length was measured after the final count in the standard germination test by randomly taken ten normal seedlings from each replication. The shoot and root length were measured from the point of attachment to the cotyledon up to the tip of the shoot and root of the seedlings, respectively. The average seedling shoot and root length were determined as per ISTA (2014). 
Seedling dry weight (mg): Ten randomly taken seedlings from each replication were placed in an envelope to dried in an oven at $80^{\circ} \mathrm{C}+1^{\circ} \mathrm{C}$ for $24 \mathrm{hrs}$. The dried seedlings were weighed using a sensitive balance.

Vigour Index I and II: For each sample, two vigor indices were calculated. Seedling vigor index I was calculated by multiplying the normal seedling length as the average sum of the shoot and root lengths after seven days of germination and vigor index II was calculated by multiplying the germination percentage with mean seedling dry weight.

Seed vigor index I = GP x SL

Where: GP is germination percentage and SL is seedling length (root length + shoot length).

Seed Vigor index II = GP x SDW (mg)

Where: GP germination percentage and SDW is a seedling dry weight

\subsection{Data Analysis}

The data collected from laboratory experiment were subjected to analysis of variance (ANOVA) for the respective design as per the procedures indicated by Gomez and Gomez (1984). The GenStat (16 ${ }^{\text {th }}$ edition) software (GenStat, 2014) was used to conduct data analysis. The comparison of mean values for treatment combinations was accomplished the significance of mean squares using Least Significant Difference (LSD) at 5\% probability levels.

\section{Result and discussion}

\section{Moisture content and seed weight}

The analysis of variance revealed that thousand seed weight had highly significantly affected by the main effect of the NPS fertilize and varietal difference whereas significantly affected by their interaction effects. However, moisture content of the seed not significantly influenced by the main factors and by their interaction effect. A similar finding was reported by Bethlehem (2011) which stated neither phosphorus, manure, variety nor any of their interactions had significant effects on physical quality and seed moisture content on groundnut Application of the $175 \mathrm{~kg}$ NPS ha-1 $^{-1}$ on Shorima nor Kakaba increased TSW by 21.5 and $12.34 \%$ respectively than treatment without fertilizer. Similarly, application of the $150 \mathrm{~kg}$ ha-1 on Qulqulu variety increased thousand seed weight by $17.17 \%$ than treatment without fertilizer. The maximum mean $(48.95 \mathrm{~g})$ value of the thousand seeds weight was obtained for Kakaba variety with field application of $\left(175 \mathrm{~kg} \mathrm{ha}^{-1}\right)$ without significant difference between treatment that received 50,125 and $150 \mathrm{~kg} \mathrm{ha}^{-1}$ and Shorima that received 50,100, and $175 \mathrm{~kg} \mathrm{NPS} \mathrm{ha}^{-1}$. The lowest mean value $(39.13 \mathrm{~g})$ was obtained from Qulqulu without fertilizer but did not significantly different with treatment that supplied with 25 to 125 and $175 \mathrm{~kg} \mathrm{ha}^{-1}$ and Shorima that received with 0,25, $75 \mathrm{~kg}^{\mathrm{NPS}} \mathrm{ha}^{-1}$ and Kakaba that received $75 \mathrm{~kg} \mathrm{ha}^{-1}$ (Table 1). The result showed that in response to blended NPS fertilizer the thousand seed weight increased significantly. This might be due to the good nutrition of the mother plant during growth up to the physiological maturity. This suggestion is in agreement with the finding of Kaleem et al. (2009) who reported that higher rates of fertilizer application produced heavyweight seeds. The variation that exists between varieties infield application of NPS fertilizer might be due to the genetic difference of the variety which ability to take up nutrient differently during development and maturity period. This result is in line with Ali et al. (2008) showed that the larger variation in thousand weight may be due to the diverse genetic makeup of wheat cultivars and their differential response to nutrient and prevalent environment during the grain filling stage.

The highest thousand seed weight had the ability to supply enough amount of food during germination of seed and had a great contribution to the germination and seed vigour. This current result was in conformity with the reports of Noor-Mohammad et al. (2000); and Cordazzo (2002) who noted that high thousand seed weight would increase germination percent, seedling emergence, tillering, density, spike, and yield.

\section{Dead seedlings}

Dead seeds had highly and significantly affected by the main effect of fertilizer and interaction effect, respectively, however, the main effect of the variety had no significant effect on the percentage of dead seeds. The highest percentage of dead seeds $(2.576 \%)$ was observed on the $50 \mathrm{~kg} \mathrm{ha}^{-1}$ NPS fertilizer interact with Shorima variety and the lowest percentage $(1.127 \%)$ of dead seed was also recorded on the $175 \mathrm{~kg} \mathrm{ha}^{-1}$ NPS fertilizer rate with Qulqulu varieties (Table1). Generally, the present study showed that the further application of blended NPS fertilizer reduces dead seeds of bread wheat varieties. The possible reason for this would be NPS fertilizer facilitates seed germination and seedling development of the seed. Varieties showed differences in the mean value of died seed percentage interact with NPS fertilizer rate. This might be a varietal difference of the crops respond to fertilizer utilization which reduces dead seed by increasing germination percentage of the seed that grows into normal seedlings and it might be the varietal vigourisity of the seed that ability to germinate earlier at the time of planting. This result is contradicted with Tesfaye (2015) who concluded that the main effects of varieties were not significant affect on the percentage of dead seeds on bread wheat varieties. Generally, there were not seen parameters like hard seed and fresh ungerminated seed on present study. 
Table 1. Interaction effect of the blended NPS fertilizer and varietal difference on the dead seeds percentage and thousand seed weight of wheat

\begin{tabular}{|c|c|c|c|c|c|c|}
\hline \multicolumn{7}{|c|}{ Varieties } \\
\hline \multicolumn{3}{|c|}{ Dead seedlings } & \multicolumn{4}{|c|}{ Thousand seed weight } \\
\hline $\begin{array}{l}\text { Blended NPS fertilizer } \\
\text { (kg ha-1) }\end{array}$ & Shorima & Kakaba & Qulqulu & Shorima & Kakaba & Qulqulu \\
\hline 0 & $2.447^{\mathrm{abc}}$ & $2.078^{\mathrm{a}-\mathrm{e}}$ & $2.447^{\mathrm{abc}}$ & $40.21^{\mathrm{hij}}$ & $43.57^{\mathrm{e}-\mathrm{h}}$ & $39.13^{\mathrm{j}}$ \\
\hline 25 & $1.924^{\mathrm{b}-\mathrm{f}}$ & $2.476^{\mathrm{ab}}$ & $2.446^{\mathrm{abc}}$ & $39.4^{\mathrm{ij}}$ & $44.44^{\mathrm{d}-\mathrm{g}}$ & $39.26^{\mathrm{j}}$ \\
\hline 50 & $2.57^{\mathrm{a}}$ & $1.435^{\mathrm{fg}}$ & $2.122^{\mathrm{a}-\mathrm{e}}$ & $42.57^{\mathrm{a}-\mathrm{f}}$ & $48.14^{\mathrm{abc}}$ & $40.29^{\text {hij }}$ \\
\hline 75 & $1.781^{\mathrm{def}}$ & $2.108^{\mathrm{a}-\mathrm{e}}$ & $1.564^{\mathrm{efg}}$ & $41.33^{\mathrm{f}-\mathrm{j}}$ & $42.63^{e-j}$ & $41.17^{\mathrm{g}-\mathrm{j}}$ \\
\hline 100 & $2.111^{\mathrm{a}-\mathrm{e}}$ & $1.789^{\mathrm{def}}$ & $1.726^{\mathrm{d}-\mathrm{g}}$ & $45.4^{\mathrm{a}-\mathrm{e}}$ & $42.98^{\mathrm{e}-\mathrm{i}}$ & $39.14^{j}$ \\
\hline 125 & $2.329^{\mathrm{a}-\mathrm{d}}$ & $2.004^{\mathrm{a}-\mathrm{f}}$ & $1.904^{\mathrm{b}-\mathrm{f}}$ & $44.92^{\mathrm{c}-\mathrm{f}}$ & $45.83^{\mathrm{a}-\mathrm{e}}$ & $40.37^{\text {hij }}$ \\
\hline 150 & $1.705^{\text {efg }}$ & $1.637^{\text {efg }}$ & $1.845^{\mathrm{c}-\mathrm{f}}$ & $45.24^{\mathrm{b}-\mathrm{e}}$ & $47.7^{\mathrm{a}-\mathrm{d}}$ & $45.85^{\mathrm{a}-\mathrm{e}}$ \\
\hline 175 & $1.564^{\mathrm{efg}}$ & $1.851^{\mathrm{c}-\mathrm{f}}$ & $1.127^{\mathrm{g}}$ & $48.86^{\mathrm{ab}}$ & $48.95^{\mathrm{a}}$ & $42.65^{e-j}$ \\
\hline $\operatorname{LSD}(5 \%)$ & 0.606 & & & & & 3.67 \\
\hline
\end{tabular}

A mean value within a column followed by the same letter (s) are not significantly different at $5 \%$ level of the significance according to list significance test' $\mathrm{LSD}=$ least significant difference at $\mathrm{P}<0.05$.

\section{Germination percentage and speed of germination}

Analysis of variance showed that the germination percentage and speed of germination had highly and significantly influenced by the main effect of the NPS fertilizer respectively, whereas highly significantly influenced by bread wheat varieties. However, both of the parameters were not influenced by their interaction effect.

The maximum (95.17\%) germination percentage and (30.41) speed of the germination were observed due to the application of 150 and $175 \mathrm{~kg}$ NPS ha- ${ }^{1}$ fertilizer level respectively. Significantly, 5.57 and 1.59 mean differences were observed plot that received $175 \mathrm{~kg} \mathrm{ha}^{-1}$ than without fertilizer (Table 2). Since the lowest germination, percentage (89.6\%) and speed germination (28.82) were recorded on control treatment. This indicates that as NPS fertilizer increases, increase germination and speed of germination of the seed. This suggestion is related with Deressa (2013) who said that the highest percentage of normal seedlings (germination) (93.3\%) was obtained in response to the application of $120 \mathrm{~kg} \mathrm{~N} \mathrm{ha}^{-1}$ and the lowest percentage $(88.6 \%)$ was obtained at $30 \mathrm{~kg}$ $\mathrm{N} \mathrm{ha}^{-1}$. The reason might be due to $\mathrm{N}, \mathrm{P}$ and $\mathrm{S}$ are the main components of the cell that facilitate activity during cell division, which is a sequential event in seed germination. The present study was in agreement with White and Veneklaas (2012) who found that NP fertilizer increase speed of germination and germination by playing an important role in energy supplying and cell biosynthesis reactions, especially during germination seedling establishment. Gemechu, (2011) also reported that the highest speed of germination and germination percentage were obtained due to the application of the highest amount of $\mathrm{N}$ and $\mathrm{P}$ fertilizer than control treatments on maize.

Qulqulu and Kakaba had 2.68\% and 2.44\% germination percentage and fast speed of germination without significant difference between them than Shorima variety respectively (Table 2). This might be due to the genetic makeup of the crop differ in its potentials for physiological activities during seed germination. Similarly, Strelec et al. (2010) had also found variation in germination percentage might be inherent nature of the crop itself on three varieties of wheat. The varieties, which had high germination percentage and speed of the germination, could be considered high quality seeds. This is because the germination percentage and speed of germination is one of the seed quality and vigourisity parameters. Daniel, (1973) indicated that seed vigour was an indication potential of seeds for rapid and uniform germination and fast seedling growth under general field conditions, or may be an indication of superior performance. Similarly, Perry (1978) who defined seed vigour is the sum total of those properties of seed that determine the potential attributes of the seed expressed during the process of germination and seedling growth. Khan, et al. (2005) also showed that quality seed plays an important role in germination and seedling vigour and ultimately for seed yield.

\section{Seedling length, dry weight, and vigour}

The analysis of variance revealed that seedling length (shoot and root), seedling dry weight and seed vigour (vigour index I and II) were significantly influenced by the main effect of the varietal difference and NPS fertilizers. However, none of the parameters were not affected by interaction effects. The application of $175 \mathrm{~kg} \mathrm{ha}^{-1}$ and 150 NPS $\mathrm{kg} \mathrm{ha}^{-1}$ fertilizer increased shoot and root length of seedlings by $8.78 \%$ and $4.99 \%$ than treatment without fertilizer respectively (Table 2).

Generally, as the current finding showed that the NPS fertilizer increased root and shoot length of the bread wheat varieties. The reason might be phosphorus fertilizer increase early root development, N, and S used for rapid development of the shoot length. Similarly, Alam et al. (2003) reported that increasing N and S fertilizer level had 
a significant main effect on the shoot and root dry weight of maize.

Significantly, Qulqulu and Kakaba had a higher shoot and root length $(9.48 \mathrm{~cm}$ and $11.32 \mathrm{~cm})$ than Shorima variety (Table 2). This might be the response to varietal difference during germination and seedling emergence. This result is also in agreement with (Kandil, et al. 2012) showed that wheat cultivars showed different in germination, seedling length, and development. Similarly, Alemayehu (2015) found that germination and speed of germination had significantly affected by the varietal difference of wheat. Varieties which had the highest seedling length had ability to absorb nutrients from the deep soil and can withstand any stress conditions during growth and developments in the field (Zewdie, 2004).

The application of $150 \mathrm{~kg}$ NPS rate increased seedling dry weight by $26.29 \%$ than treatment without fertilizer. The treatment that received 100 to $175 \mathrm{~kg} \mathrm{NPS} \mathrm{ha}^{-1}$ and similarly 50 to 125 and $175 \mathrm{~kg} \mathrm{NPS} \mathrm{ha}^{-1}$ had not showed significant difference (Table 2). As increasing fertilizer level seedling, dry weight increases. The reason might be NPS fertilizer had contributions to shoot, root development. This is related with finding of Gemechu (2011); who reported that increasing nitrogen and phosphorus fertilizer increased seedling dry weights of maize.

Significantly, higher seedling dry weight $(23.98 \mathrm{mg})$ was recorded for the Kakaba variety without significant different with Qulqulu and the lowest value $(22.59 \mathrm{mg})$ was obtained with Shorima variety. This might be varietal differences in seedling development that increases dry weight. This suggestion is related to Testate (2015) who found that seedling dry weight is significantly affected by the main effect of the wheat varieties.

Seed vigor determines its potential for rapid, uniform emergence and development under a wide range of field conditions. Application of the 175 and $150 \mathrm{~kg} \mathrm{ha}^{-1}$ increased seedling vigour index I and II by $12.9 \%$ and $19.8 \%$ than control treatment respectively (Table 2). This might be the highest standard germination and the highest seedling value due to the increasing rate of NPS fertilizer. Gore et al. (1997) reported that higher seedling vigour index I and II was probably due to the associated effect of germination percentage and seedling length. Similarly, Haile and Nigussie (2013) reported that significant effect of field Nitrogen application and timing on seed germination speed, seedling dry weight, and seedling vigor index on bread wheat varieties. Similarly, Gemechu (2011) who reported that the highest vigor index I and II was recorded from N and P application at the rate of 138 $\mathrm{kg} \mathrm{NPS} \mathrm{ha}{ }^{-1}$. Seeds that had a higher viguor index considered more vigorous. Therefore, vigour index is one of the indicators of main seed quality parameter.

Qulqulu and Kakaba varieties had higher vigour index I and II (19.31 and 22.28) without significant difference between them than Shorima variety respectively. The difference might be due to the genetic makeup of the crop may differ in the vigour performance. Similarly, (Kandil, et al. 2012) suggested that wheat varieties showed significantly different in seedling vigour due to their inherent nature of the crop.

\section{Abnormal seedlings}

Analysis of results indicated that the abnormal seedling had highly significantly affected by the fertilizer and varietal difference and not significantly affected by their interaction effects. The lowest percentage of abnormal seedlings (1.454\%) observed on the $150 \mathrm{~kg}$ blended NPS fertilizer, without significant difference between plot that received 50 to $125 \mathrm{~kg}$ and $175 \mathrm{~kg}$ NPS ha ${ }^{-1}$ fertilizer. Maximum percentage of abnormal seedling $(2.456 \%)$ recorded from the control treatment without significant difference between treatments that received 25 to $75 \mathrm{~kg}$ (Table 2). Generally, seeds, which had highest field application NPS fertilizer, had lowest abnormal seedlings and the lowest application of field NPS fertilizer had highest abnormal seedlings. According to this result, further application of blended NPS fertilizer decreased the percentage of abnormal seedling, which means that the abnormal plant growth could be more increased at low level of NPS application than a higher level of application. This is because of phosphorus, nitrogen, and Sulphur is constituent of nucleic acids, ATP, and activates enzymes for normal seedling germination and growth. The maximum percentages $(2.322 \%)$ of abnormal seedlings had seen in the Shorima variety and the lowest percentage of abnormal (1.844\%) seedling was recorded on the Qulqulu variety. Therefore, Qulqulu variety had high potential to produce more quality and normal seedling than other varieties studied. This makes genetic makeup of plants differ in ability to grow more vigorously. 
Table 2. Effect of blended NPS fertilizer and wheat varieties on Seedling shoots and root length, seedling dry weight, seed vigour index I and II, and abnormal seedlings

\begin{tabular}{lllllllll}
\hline $\begin{array}{l}\text { NPS fertilizer } \\
\left(\mathrm{kg} \mathrm{ha}^{-1}\right)\end{array}$ & GP $(\%)$ & SG & SL(cm) & RL $(\mathrm{cm})$ & DW(mg) & SVI I & SVI II & AS (\%) \\
\hline 0 & $89.67^{\mathrm{e}}$ & $28.82^{\mathrm{b}}$ & $8.77^{\mathrm{d}}$ & $10.81^{\mathrm{d}}$ & $22.17^{\mathrm{c}}$ & $17.56^{\mathrm{d}}$ & $19.88^{\mathrm{d}}$ & $2.456^{\mathrm{a}}$ \\
25 & $90.50^{\mathrm{de}}$ & $29^{\mathrm{b}}$ & $8.84^{\mathrm{d}}$ & $10.76^{\mathrm{d}}$ & $22.36^{\mathrm{c}}$ & $17.74^{\mathrm{cd}}$ & $20.24^{\mathrm{d}}$ & $2.378^{\mathrm{a}}$ \\
50 & $91.17^{\text {cde }}$ & $29.11^{\mathrm{b}}$ & $8.94^{\mathrm{cd}}$ & $11^{\mathrm{c}}$ & $22.75^{\mathrm{bc}}$ & $18.18^{\mathrm{c}}$ & $20.73^{\mathrm{d}}$ & $2.241^{\mathrm{ab}}$ \\
75 & $92.50^{\mathrm{cd}}$ & $29.55^{\mathrm{ab}}$ & $9.2^{\mathrm{bc}}$ & $11.14^{\mathrm{bc}}$ & $22.75^{\mathrm{bc}}$ & $18.81^{\mathrm{b}}$ & $21.02^{\mathrm{cd}}$ & $2.231^{\mathrm{ab}}$ \\
100 & $93.00^{\mathrm{bc}}$ & $29.67^{\mathrm{ab}}$ & $9.32^{\mathrm{ab}}$ & $11.3^{\mathrm{ab}}$ & $23.83^{\mathrm{ab}}$ & $19.18^{\mathrm{b}}$ & $22.17^{\mathrm{bc}}$ & $1.987^{\mathrm{b}}$ \\
125 & $92.50^{\mathrm{cd}}$ & $29.56^{\mathrm{ab}}$ & $9.47^{\mathrm{ab}}$ & $11.28^{\mathrm{ab}}$ & $24.00^{\mathrm{ab}}$ & $19.27^{\mathrm{b}}$ & $22.3^{\mathrm{b}}$ & $1.928^{\mathrm{b}}$ \\
150 & $95.17^{\mathrm{a}}$ & $30.16^{\mathrm{a}}$ & $9.45^{\mathrm{ab}}$ & $11.35^{\mathrm{a}}$ & $25.00^{\mathrm{a}}$ & $19.81^{\mathrm{a}}$ & $23.82^{\mathrm{a}}$ & $1.454^{\mathrm{c}}$ \\
175 & $95.00^{\mathrm{ab}}$ & $30.41^{\mathrm{a}}$ & $9.54^{\mathrm{a}}$ & $11.33^{\mathrm{a}}$ & $23.92^{\mathrm{ab}}$ & $19.83^{\mathrm{a}}$ & $22.72^{\mathrm{ab}}$ & $1.929^{\mathrm{b}}$ \\
\hline LSD (5\%) & 2.073 & 0.905 & 0.302 & 0.187 & 1.27 & 0.523 & 1.2 & 0.342 \\
\hline Varieties & & & & & & & & 2.32 \\
\hline Shorima & $91^{\mathrm{b}}$ & $29.11^{\mathrm{b}}$ & $8.81^{\mathrm{c}}$ & $10.9^{\mathrm{c}}$ & $22.59^{\mathrm{b}}$ & $17.94^{\mathrm{b}}$ & $20.58^{\mathrm{b}}$ & $2.322^{\mathrm{a}}$ \\
Kakaba & $92.88^{\mathrm{a}}$ & $29.82^{\mathrm{a}}$ & $9.29^{\mathrm{b}}$ & $11.32^{\mathrm{a}}$ & $23.47^{\mathrm{a}}$ & $19.15^{\mathrm{a}}$ & $22.28^{\mathrm{a}}$ & $2.061^{\mathrm{b}}$ \\
Qululu & $93.44^{\mathrm{a}}$ & $29.68^{\mathrm{a}}$ & $9.48^{\mathrm{a}}$ & $11.15^{\mathrm{b}}$ & $23.98^{\mathrm{a}}$ & $19.31^{\mathrm{a}}$ & $21.97^{\mathrm{a}}$ & $1.844^{\mathrm{c}}$ \\
\hline LSD $(5 \%)$ & 1.269 & 0.554 & 0.185 & 0.155 & 0.777 & 0.32 & 0.7 & 0.209 \\
\hline
\end{tabular}

Mean value within column followed by same latter(s) are not significantly different at 5\%; LSD= least significant difference at $\mathrm{P}<0.05 ; \mathrm{GP}=$ germination percentage, $\mathrm{SG}=$ Speed of germination, $\mathrm{RL}=$ root length; $\mathrm{DW}=$ dry weight; SVI I =seed vigour index I; SVI II=seed vigour index II, AS=Abnormal Seedlings

\section{Summary and conclusion}

The production of high seed yield with desirable seed quality in wheat is highly influenced by the type(s) and amount of fertilizers application. Moreover, the effect of newly synthesized blended NPS fertilizer on seed yield and seed quality has not been studied in Haramaya district, Eastern Ethiopia. Therefore, this study was conducted to asses' effect of blended NPS fertilizer and varieties on seed quality of the bread wheat. The research results indicated that the variety as well as the rates of blended fertilizer had significant influence on seed yield and seed quality. The application of $150 \mathrm{~kg}$ NPS ha- ${ }^{-1}$ and Qulqulu variety produced highest seed quality values for most of the seed quality parameters. The growing of Qulqulu variety with the application of $150 \mathrm{~kg} \mathrm{NPS} \mathrm{ha}^{-1}$ had highest benefit than any other treatment combinations. Therefore, it can be concluded that the application of $150 / 175 \mathrm{~kg}$ NPS ha ${ }^{-1}$ and the growing of Qulqulu variety could be better choice of the farmers of the study area to obtain high seed.

\section{Acknowledgments}

My grateful thanks go to ministry of education, which was supporting me financially during the period of the study and Haramaya University, which was allowing me to use their land for this study. I express my deepest thanks to my research advisors, Dr. Wassu Mohammed (PhD) and Mr Amare Kebede (asst Prof.) for their continuous encouragement, guidance and valuable suggestions in every step of the research work.

\section{Reference}

Alam, M.M., Islam, Md.N., Rahman, M.S, Halaluddin, Md. and Hoque. M. Md. 2003. Effect of Sulfur and Nitrogen on the yield and seed quality of maize (cv. Barnali). Online journal of biological sciences, 3 (7):643654.

Alemayehu Adinew. 2015. Effect of seed sources and rates on the productivity of bread wheat varieties at Kersa, Eastern Ethiopia. M.Sc Thesis. Haramaya University, Haramaya, Ethiopia

Ali, R., Khan, M.J. and Khattak, R.A. 2008. Response of rice to different sources of Sulfur (S) at various levels and its residual effect on wheat in rice-wheat cropping system. Soil Environ, 27:131-137

Amare Aleminew, Adane Legas, and Mekonen Misganaw. 2015. Yield Response of Bread Wheat to Timing of Urea Fertilizer Application in Eastern Amhara Region. Sirinka Agricultural Research Center, Woldia, Ethiopia. Journal of Biology, Agriculture, and Healthcare, 5 (3):180-183.

Bethelem Melese. 2011. Seed Yield and Quality of Groundnut (Arachis hypogaea L.) as Influenced by Phosphorus and Manure Application at Babile, Eastern Ethiopia MSc. Thesis in Agriculture. Haramaya University, Haramaya Ethiopia.

Bewley, JD. and Black, M.1994. Seeds Physiology of Development and Germination, $2^{\text {nd }}$ Edition. Plenum Press, New York. Plenum Press).Seed Science Research, 5(2):127-128.

Brady, N.C. and Weil, R.R. 2002. The nature and properties of soils, $13^{\text {th }}$. Pearson education (Singapore) Pte. Ltd. Indian Branch, 482:621-624. 
Cordazzo, C.V. 2002. Effect of seed mass on germination and growth in three dominant species in southern Brazilian coastal dunes. Brazilian Journal of Biology, 62(3):427-435.

CSA (Central Statistical Authority). 2016. Agricultural sample survey 2015/16. Volume I. Report on area and production of major crops for private peasant holdings, meher season. Statistical bulletin 584. Central Statistical Agency, Addis Ababa, Ethiopia.

EthioSIS (Ethiopian Soils Information System). 2013. Status of soil resources in Ethiopia and priorities for sustainable management, GSP for eastern and southern Africa Mar 25-27 Nairobi, Kenya FAO (Food and Agriculture Organization of the United Nations).1984. Ethiopian highlands reclamation study (EHRS). Final Report, Vols. 1-2, Rome.

FAOSTAT (Food and Agriculture Organization of the United Nations). 2013. World crop production data. Available at: (http://www.faostat.fao.org/site. Accessed on February 20, 2018.

Gemechu Gerba. 2011. Influence of Nitrogen and Phosphorus Fertilizers on Seed Yield and Quality of Maize (Zea mays L.) at Bedele, Southwestern Ethiopia. MSc Thesis. Haramaya University, Haramaya Ethiopia.

GenStat.2014. GenStat Procedure Library Release $16^{\text {th }}$ Edition. VSN International Ltd.

Gomez, A.K. and Gomez A.A.1984. Statistical Procedures for Agricultural Research, $2^{\text {nd }}$ Edition. John Wiley and Sons, New York, USA.

Haile Deressa, and Nigussie Dechassa .2013. Seed and Seedling Performance of Bread Wheat (Triticum aestivum L.) as Influenced by Rate and In-Season Nitrogen Application. American Journal of Experimental Agriculture, 3(4):857-870.

Hailu Gebre-Mariam.1991. Bread wheat breeding and genetics research in Ethiopia. Wheat research in Ethiopia: A historical perspective, pp.73-93.

ISTA (International Rules for Seed Testing Association).2014. International Seed Testing Association, Bassersdorf, Switzerland

Kaleem S., Ansarm.,Ali M., Sher A. and Rashid M. 2009. Effect of Phosphorus on the Yield and Yield Components of Wheat Variety Inqlab-91 Under Rainfed Conditions Sarhad Journal of Agriculture, 25(1):1989-1992.

Kandil, A. A., Sharif, A.E. and Elokda, M. A. 2012. Germination and Seedling characters of Different Wheat Cultivars under Salinity Stress. Journals of Basic and Applied sciences, 8:585-596.

Khan, A. Jan, A.M. Bashir, S. and Noor, M. 2005. Short Communication Effect of Nitrogen and Seed size on Maize Crop. i: Stand and Plant Height. J. Agri. \& Soc. Sci, 1(4):380-381

Ministry of Agriculture and Rural Development. 2009. Animal and Plant Health Regulatory Directorate, crop variety register, Issue No.12.

Nguyen, V. N. 2001. Rice production, consumption, and nutrition. FAO, Rome.

Noor Mohammadi, Gh. Siadat, A. and Kashani, A. 2000. Agronomy (cereal). Ahwaz University Press. Pp446.

Perry, D.A. 1978. Report of the major test committee .pp 1974-1977. Seed Science and Technology, 6:159-181

Strelec, I., Popovich, R., Jurcovic, V., Jurcovic, Z., Hardi, Z. and Sabo, M. 2010. Influence of temperature and relative humidity on grain moisture, germination and vigour of three wheat cultivars during one year storage. Poljoprivreda, 16(2):20-24.

Tesfaye Geleta .2015. Seed Rate and Sowing Method Effects on Seed Quality of Bread Wheat (Triticum aestivum L.) Varieties in Horo District, Western Ethiopia', Malays. j. med. biol. res., 2(3):273-283.

Veneklaas, E.J., Lambers, H., Bragg, J., Finnegan, P.M., Lovelock, C.E., Plaxton, W.C., Price, C.A., Scheible, W.R., Shane, M.W., White, P.J. and Raven, J.A., 2012. Opportunities for improving phosphorus-use efficiency in crop plants. New Phytologist, 195(2), pp.306-320.

Zewdie Bishaw.2004. Wheat and Barley Seed Systems in Ethiopia and Syria. PhD. Thesis Wageningen University pp10-325.ISBN:90-8504. 